THE CANADIAN JOURNAL OF AUTISM EQUITY LA REVUE CANADIENNE DE L'ÉQUITÉ EN MATIÈRE D'AUTISME \begin{tabular}{l|l|l} 
VOLUME 1 & ISSUE 1 & APRIL 2021
\end{tabular}

\title{
Moving From Autism Awareness to Acceptance - Language of Inclusion
}

Maddy (Matthew) Dever, Independent Researcher, Canada 


\title{
Moving From Autism Awareness to Acceptance - Language of Inclusion
}

\author{
Maddy (Matthew) Dever ${ }^{1}$ (ib
}

\begin{abstract}
For the last 50 years, April has been celebrated as Autism Awareness Month, and media campaigns and fundraisers have occurred alongside, trying to raise "awareness" of the difficulties and challenges associated with having a family member diagnosed with autism. The stigma that "awareness" continues to foster creates real barriers for Autistics to be seen as more than a stereotype. Many Autistics believe strongly that we need to move past a time of awareness and move to a time of autism "acceptance". Accepting who we are, and our different ways of thinking, acting, and presenting ourselves to the world. This video and associated transcript will look at how we can move from autism awareness to autism acceptance through a change in the language we use.
\end{abstract} Moving from words and thoughts that cause exclusion and segregation to words that promote inclusion and accommodation. Changing our language changes the way we think, changing the way we think, changes the way we act, and our actions can bring about change that will allow Autistics to thrive. If we change how we talk about autism in policy, in programs, in research and in media, we will change how autism is conceived of and start to see the barriers around Autistics come down.

Résumé

Depuis les 50 dernières années, le mois d'avril est célébré comme le mois de la sensibilisation à l'autisme. Parallèlement, des campagnes médiatiques et des collectes de fonds sont organisées pour tenter de conscientiser les gens aux difficultés et aux défis associés au fait d'avoir un membre de sa famille qui reçoit un diagnostic d'autisme. La stigmatisation que cette "sensibilisation" continue d'entretenir crée de véritables obstacles qui empêchent les personnes autistes d'être considérées autrement que de manière stéréotypée. De nombreuses personnes autistes croient fermement qu'il est temps de délaisser cette période de sensibilisation pour passer à une période $d$ ' «acceptation» de l'autisme. Il est temps de commencer à accepter qui nous sommes, ainsi que nos différentes façons de penser, d'agir et de nous présenter au monde. Cette vidéo et sa transcription examinent comment nous pouvons passer de la sensibilisation

à l'autisme à l'acceptation de l'autisme en changeant la langue que nous utilisons, en passant de mots et de pensées qui provoquent l'exclusion et la ségrégation à des mots qui favorisent l'inclusion et l'adaptation. Le fait de changer notre langue change notre façon de penser, qui, à son tour, change notre

façon d'agir. Ces nouvelles actions peuvent apporter un changement qui permettra aux personnes autistes de s'épanouir. Si nous changeons notre façon de parler de l'autisme dans les politiques, les programmes, la recherche et les

médias, nous changerons la façon dont l'autisme est perçu et nous commencerons à faire tomber les barrières qui freinent les personnes autistes.

1 Independent Researcher, Canada 


\author{
Keywords \\ Awareness, Acceptance, Language, Stigma, Inclusion \\ Mots clés \\ Sensibilisation, Acceptation, Langage, Stigmatisation, Inclusion
}

\title{
Minute 1 - History of Awareness
}

It's April once again.

With that come the usual things like rain, walks outdoors, flowers, gardening, all the signs of Spring, Passover, Easter; and Autism Awareness Month.

Autism Awareness Month has been experienced in some form over the last 50 years, starting in the United States as a means to inform the public and government of the challenges of autism, and the difficulties in parenting Autistic children (Autism Society, n.d.).

Campaigns of Autism awareness began by National Autism Society in the US in 1970, and the first National Autistic Children's Week was observed in 1972 (Autism Society). This later evolved into what is now Autism Awareness Month that takes place every April in many countries throughout the world.

In 2008, after the adoption of the UN Charter of Rights for Persons with Disabilities, the UN passed a resolution (United Nations) to mark April 2nd as the day chosen to celebrate World Autism Awareness Day every year.

So after over 50 years of Awareness what has been the effect on the supports, services and quality of life of Autistic People. Has awareness been a benefit to us? Has it allowed us to thrive?

\section{Minute 2 - What is awareness?}

So what does awareness look like and why have autism advocates focussed on it?

In the past it was felt there was a need to let the public know what parents struggled with raising autistic children and push for increased funding for therapies and research.

The focus on awareness flows from the medical model of disability which looks at autism through its perceived deficits (Kapp, 2019). Many of the terms used to describe autism focuses on what we can't do, and emphasizes that parents need to get therapies that can intervene and fix their child (Kapp, 2019).

Some of the terms we hear in the medical model are: deficit, intervention, symptoms, red flags, risks, "special needs", as well as talk of an increasing "Autism Epidemic" (Lilienfeld et al. 2015).

In describing autism, Autistics are frequently compared negatively to their non-autistic 
peers in how we communicate, our social skills, and in our "behaviours" (Sasson et al. 2017).

However, evidence shows us that "awareness" doesn't actually educate the public about autism or Autistic people (Alsehemi et al. 2017), and it doesn't help them to understand what our needs are, or what accommodations might be needed to help us thrive in schools, in the community and in the workplace.

Awareness instead becomes another barrier and leads to continued fear and stigma, for people to be watchful and concerned.

Autism awareness has run its course.

\section{Minute 3 - Introducing Autism Acceptance}

So let's talk about Acceptance.

The concepts behind Autism Acceptance come from the social model of disability, developed by disability rights activists (National Disability Arts Collection and Archive, n.d.). In it we are disabled by the barriers that exist in society, not by any internal impairment or difference. The barriers we experience can be physical but they can also be systemic attitudes of what we can or cannot do.

Autistics want to be accepted for who they are and how they think and do things.

For the last 10 years Autistics have been trying to change this message every April by instead celebrating Autism Acceptance Day and Month. Acceptance changes the focus on what we CAN do, not what we can't do.

Now, after 10 years, other autism-focussed organizations are beginning to make the same change, including National Autism Society in the US where the original Autism Awareness started (Autism Society), and CASDA - The Canadian Autism Spectrum Disorder Alliance. (Canadian Autism Spectrum Disorder Alliance, 2021).

They are joining autistic-led organizations and adopting Autism Acceptance Month and Day moving the conversation forward.

The message of Acceptance is that autism is not scary, it isn't something to be feared, an autism diagnosis does not mean your child is broken, and there is no "Autism Epidemic".

So the age of Autism Acceptance is here, but how do we make acceptance a reality?

\section{Minute 4 - The Language of Acceptance}

Attitudes about autism are a barrier to acceptance. The way to change those attitudes is to change the words we use to describe 'autism' and Autistic people and not be afraid to use these 
words.

In fact a majority of Autistic adults prefer using Autistic as their identity. "I am Autistic" (Organization for Autism Research, 2020; Botha et al., 2020).

Instead of 'deficit' use "challenge", "intervention" use "support", "symptoms" use "characteristic", "red flags" or "risks" use "signs", and we don't have "special needs" just needs (Bottema-Beutel et al., 2021).

The way we look at the "spectrum" needs to change from a linear to spherical view. We aren't more or less Autistic, we each have strengths and weaknesses across multiple domains and this can change from day to day, over time, and in different situations. We have varying needs for supports to meet our challenges, and some of these can be quite extensive.

There is no low or high functioning, as these labels ignore the Autistic person whose strengths in some domains may mask the significant challenges in other domains and who may be held to too high an expectation. As well, the Autistic person with challenges in more areas may be harmed by low expectations, with their strengths in other areas being ignored.

What's important is seeing our strengths, acknowledging our challenges, and supporting our needs - not our label.

Words matter.

\section{Minute 5 - Beyond Acceptance towards Full Inclusion}

If Acceptance is an idea, and is about changed attitudes, then what actions are needed to flow from acceptance? What is beyond Acceptance?

Inclusion. There is a fallacy that our world is an inclusive one, and that we are inclusive towards people with disabilities and Autistics. But "Inclusion"? I don't think they know what that means.

In the past many Autistics were segregated from their families/peers (Evans, 2013). Then came a push to mainstream and put Autistics together with their peers, in schools, and in the communities. Many called this "inclusion" and felt this was enough.

However, the actual term for this is "integration". A good first step. The next step is accommodations.

Wherever we are not accommodated, it leads to more barriers, and exclusions, and a slippery slope towards segregation again. However when our needs are understood and accommodated, we are only then truly included as we are and barriers are removed.

As a society, we need to actively tear down barriers and accommodate people's unique needs and not their labels. Let's celebrate differences great and small. 
Words can change thoughts. Thoughts change hearts. Hearts change actions. And actions can change the world.

Happy Autism Acceptance Month!

\section{ORCID iD}

Matthew Dever (iD) https://orcid.org/0000-0003-3330-7749

\section{References}

Alsehemi, M. A., Abousaadeh, M. M., Sairafi, R. A., \& Jan, M. M. (2017). Public awareness of autism spectrum disorder. Neurosciences, 22(3), 213-215. https://doi.org/10.17712/nsj.2017.3.20160525

Autism Society. (n.d.). Autism Acceptance Month. Autism Society. Retrieved June 24, 2021, from https: / / www.autism-society.org/get-involved/national-autism-awareness-month/

Botha, M., Hanlon, J., \& Williams, G. L. (2021). Does Language Matter? Identity-First Versus Person-First Language Use in Autism Research: A Response to Vivanti. Journal of Autism and Developmental Disorders. https:// doi.org/10.1007/s10803-020-04858-W

Bottema-Beutel, K., Kapp, S. K., Lester, J. N., Sasson, N. J., \& Hand, B. N. (2021). Avoiding Ableist Language: Suggestions for Autism Researchers. Autism in Adulthood, 3(1). https://doi.org/10.1089/aut.2020.0014/aut.2020.0014

Canadian Autism Spectrum Disorder Alliance. (2021, April 6). \#AutismAcceptanceMonth with CASDA. CASDA. Retrieved July 3, 2021, from https://www.casda.ca/world-autism-month-2021/

Evans, B. (2013). How autism became autism - The radical transformation of a central concept of child development in Britain. History of the Human Sciences, 26(3), 3-31. https://doi.org/10.1177/0952695113484320/10.1177/0952695113484320

Kapp, S. (2019). How social deficit models exacerbate the medical model: Autism as case in point. Autism Policy \& Practice, 2, 3-28. Retrieved from https://researchportal.port.ac.uk/portal/files/16090863/How_social_deficit_models.pdf

Lilienfeld, S. O., Sauvigne, K. C., Lynn, S. J., Cautlin, R. J., Lautzman, R. D., \& Waldman, I. D. (2015). Fifty psychological and psychiatric terms to avoid: a list of inaccurate, misleading, misused, ambiguous, and logically confused words and phrases. Frontiers in Psychology, 6, 1100. https:// doi.org/10.3389/fpsyg.2015.01100

National Disability Arts Collection and Archive. (n.d.). Fundamental Principles of Disability. NDACA. Retrieved July 3, 2021, from https: / / the-ndaca.org/resources/audio-described-gallery/fundamental-principles-of-disability/

Organization for Autism Research. (2020, September 30). 1,000 PEOPLE SURVEYED, SURVEY SAYS.... Organization for Autism Research. Retrieved July 3, 2021, from https: //researchautism.org/1000-people-surveyed-survey-says/

Sasson, N. J., Faso, D. J., Nugent, J., Lovell, S., Kennedy, D. P., \& Grossman, R. B. (2017). Neurotypical Peers are Less Willing to Interact with Those with Autism based on Thin Slice Judgments. Scientific Reports, 7(1), 1-10. https://doi.org/10.1038/srep40700

United Nations. (n.d.). World Autism Awareness Day 2 April. World Autism Awareness Day 2 April. Retrieved June 24, 2021, from https://www.un.org/en/observances/autism-day/background 